Original research article

\title{
The evaluation of oxidative damage of DNA after poisoning with nerve agents
}

\author{
Jiri Kassa *, Rudolf Stetina \\ University of Defence in Brno, Faculty of Military Health Sciences, Department of Toxicology and Military Pharmacy, Hradec Kralove, Czech Republic
}

\begin{abstract}
The potency of three nerve agents (sarin, soman, tabun) to induce oxidative damage of DNA in lymphocytes, liver and brain during lethal or sublethal poisoning was investigated. The single strand breaks or oxidative base DNA damage was evaluated with the help of Comet assay and a specific enzyme able to detect oxidative bases of DNA (endonuclease III). While sarin and soman administered at sublethal doses corresponding to $50 \%$ of their $\mathrm{LD}_{50}$ values were not able to induce oxidative damage of $\mathrm{DNA}$, their lethal dose ( $\left.\mathrm{LD}_{50}\right)$ induced the significant increase of the number of oxidative bases in DNA of hepatocytes. In addition, tabun administered at lethal dose (LD ${ }_{50}$ ) induced significant increase of the number of single strand breaks and oxidative bases of DNA in glial cells isolated from pontomedullar brain region. Thus, some nerve agents were able to induce oxidative damage in the peripheral as well as central compartment but only in the case of severe poisoning caused by lethal doses of nerve agents. This non-cholinergic effect of nerve agents has probably consequences with nerve agents-induced hypoxic status during acute cholinergic crisis and it can contribute to their long-term toxic effects.
\end{abstract}

Keywords: Comet assay; DNA; Oxidative damage; Rats; Sarin; Soman; Tabun

Highlights:

- Oxidative DNA damage was evaluated by Comet assay and a specific enzyme able to detect oxidative bases of DNA.

- Lethal dose of sarin and soman induced the significant increase of the number of oxidative bases in DNA of hepatocytes.

- Lethal dose of tabun induced significant increase of the number of oxidative bases of DNA in glial cells.

- This non-cholinergic effect of nerve agents has probably consequences with nerve agents-induced hypoxic status.

\section{Introduction}

Highly toxic organophosphorus compounds (OPC) have been developed as chemical warfare agents called nerve agents. They are considered to be the most dangerous chemical warfare agents and represent potential threats to both military and civilian populations. The most important representatives of nerve agents are tabun, sarin, soman, cyclosarin and VX. The acute toxic effects of OPC are based on the phosphonylation of acetylcholinesterase (AChE, EC 3.1.1.7), leading to the irreversible inhibition of its active site and subsequent overstimulation of postsynaptic cholinergic receptors due to the accumulation of the neurotransmitter acetylcholine in synapses of the central and peripheral nervous system (Čolović et al., 2013; Marrs, 2007). The overstimulation of cholinergic receptors results in muscarinic and nicotinic signs and symptoms including excitotoxicity, seizures and brain damage. The death is usually caused by respiratory failure resulting from bronchospasm, excessive bronchial secretion, paralysis of respiratory muscles, and depression of brain respiratory centers (Bajgar, 2004; Delfino et al., 2009).
However, the mechanism of acute and chronic toxicity of OPC is much more complex. There are adverse health effects connected with OPC toxicity that are not related to AChE inhibition and direct cholinergic receptors overstimulation. The mechanisms of these adverse effects of OPC, called non-cholinergic or non-specific effects, are still under extensive research. OPC have many non-specific effects involving the activation of multiple non-cholinergic neurotransmitter systems in the central nervous system, mutagenic, stressogenic, immunotoxic, hepatotoxic, membrane and hematotoxic effects (Bajgar, 2004). OPC-induced glutamate-mediated excitotoxicity (O’Donnell et al., 2011), calcium overload (Choi, 1988), ATP depletion and cellular energy loss (Gupta et al., 2001), alteration of immune functions (Kassa et al., 2000a) and DNA damage (Kassa et al., 2000b; Mehta et al., 2008; Ojha et al., 2013) were also described in the literature. The non-specific effects of OPC are considered to contribute to their long-term toxic effects, therefore, it is important to find the mechanism of the non-specific effects of OPC at the cellular and molecular level. Understanding of the mechanism of non-specific effects of OPC might contribute to the early diagnosis and complex treatment of OPC poisoning (Čolović et al., 2013).

\footnotetext{
* Author for correspondence: Jiri Kassa, University of Defence in Brno, Faculty of Military Health Sciences Hradec Kralove, Trebesska 1575, 50001 Hradec Kralove, Czech Republic; e-mail: kassa@pmfhk.cz http://doi.org/10.32725/jab.2019.017

Submitted: 2019-05-29 • Accepted: 2019-11-06 • Prepublished online: 2019-11-13

J Appl Biomed 17/4: 225-230 • EISSN 1214-0287 • ISSN 1214-021X

(c) 2019 The Authors. Published by University of South Bohemia in České Budějovice, Faculty of Health and Social Sciences.

This is an open access article under the CC BY-NC-ND license.
} 
One of the most important non-specific effects of OPC is the development of oxidative stress that is simply defined as a serious imbalance between enhanced generation of reactive oxygen species (ROS), nitrogen species (RNS) and antioxidant defence, results in disruption of a cellular redox state and associated macromolecular damage. Oxidatively modified biomolecules formed during nitration and carbonylation of proteins, peroxidation of lipids and oxidation of DNA cause deterioration of cellular structural architecture and disturbances in physiological processes and intracellular signaling (Ischiropoulos and Beckman, 2003).

OPC-induced oxidative stress is connected with OPC-induced excitotoxicity, mitochondrial dysfunction and inhibition of endogenous antioxidant capacity. Calcium homeostasis (sustained elevation of intracellular calcium), cellular respiration, the production of ROS, and control of apoptotic cell death have all been reported to be altered in OPC models, even at low concentrations of OPC (Pearson and Patel, 2016). Mitochondrial dysfunction in the central nervous system and other tissues, which was found to occur in OP pesticide poisoning (Karami-Mohajeri and Abdollahi, 2013) and in nerve agent exposure (Collombet et al., 2009), has a causal role in the elicitation of oxidative imbalance and apoptosis. In vitro studies of the effects of OP pesticides have shown that their apoptotic effects are mediated via mitochondrial signaling pathway and driven by oxidative rather than cholinergic processes (Karami-Mohajeri and Abdollahi, 2013). The mitochondrial dysfunction may be a causal factor in the generation of OPC-induced seizures (Folbergova and Kunz, 2012). Specifically, a dose of chlorpyrifos, not sufficient to inhibit AChE, significantly increased mitochondria fusion versus fission events and decreased axonal mitochondrial transport (Middlemore-Risher et al., 2011). It was found that both acute and subacute exposure to OPC are sufficient to decrease activities of key antioxidants (glutathione peroxidase, glutathione reductase, GSH, SOD and calalase) that is connected with OPC-induced oxidative stress (Brocardo et al., 2005; Kaur et al., 2007).

One of the symptoms of OPC-induced oxidative stress is considered to be the oxidative damage of DNA. The aim of the study is to evaluate the presence and intensity of oxidative damage of DNA in lymphocytes, hepatocytes and brain cells after sublethal or lethal poisoning of rats with nerve agents.

\section{Materials and methods}

\section{Animals}

Male Wistar albino rats weighing 180-200 g were purchased from VELAZ (Prague, Czech Republic). They were kept in an air-conditioned room $\left(22 \pm 2{ }^{\circ} \mathrm{C}\right.$ and $50 \pm 10 \%$ relative humidity, with lights from 7 a.m. to 7 p.m.) and allowed access to standard food and tap water ad libitum. The rats were divided into groups of six to sixteen animals $(N=6-16)$. Handling of experimental animals was done under the supervision of the Ethics Committee of the Faculty of Military Health Sciences in Hradec Králové (Czech Republic).

\section{Cells}

Human embryonic lung fibroblasts were obtained from the Institute of Sera and Vaccines (Prague, Czech Republic). Cells were incubated in medium MEM (PAA) supplemented with foetal bovine serum (Biotech, Prague, Czech Republic). They were passaged once a week in the ratio $1: 2$ by trypsinisation.

\section{Chemicals}

Nerve agents (sarin, soman, tabun) were obtained from the Military Technical Institute in Brno (Czech Republic) and were 90-95\% pure as assayed by acidimetric titration. The basic solution of nerve agents $(1 \mathrm{mg} / \mathrm{ml})$ was prepared in propyleneglycol three days before starting the experiments. Actual solution of tested nerve agent was prepared from its basic solution with the help of saline immediately before administration. All other drugs and chemicals of analytical grade were obtained commercially and used without further purification. The saline solution $(0.9 \% \mathrm{NaCl})$ was used as a vehicle. All substances were administered intramuscularly (i.m.) at a volume of $1 \mathrm{ml} / \mathrm{kg}$ body weight (b.w.).

\section{Comet assay}

The Comet Assay, also called single cell gel electrophoresis (SCGE), is a sensitive and rapid technique for quantifying and analyzing DNA damage including oxidative DNA damage in individual cells (Kucharova et al., 2019). The alkaline comet assay was basically performed following the Singh's protocol (Singh et al., 1988). Thirty five $\mu \mathrm{l}$ of the suspension was mixed with $85 \mu \mathrm{l}$ of $1 \%$ low melting point agarose and $85 \mu \mathrm{l}$ of this suspension was pipetted onto slides pre-coated with high melting point agarose (Serva Electrophoresis $\mathrm{GmbH}$ ). After solidifying of the agarose, the slides with gels were placed in a lysis buffer [pH $10.4{ }^{\circ} \mathrm{C}$; $100 \mathrm{mM}$ EDTA, $2.5 \mathrm{M} \mathrm{NaCl}, 10 \mathrm{mM}$ Tris (all from Penta, Prague, Czech Republic) and 1\% Triton X-100 (Serva Electrophoresis $\mathrm{GmbH}$ )] for $1 \mathrm{~h}$. A modification of the comet assay according to Collins et al. (1996) was used further. At this stage, $50 \mu$ l of the endonuclease III solution were added to parallel slides and slides were incubated for $30 \mathrm{~min}$ at $37^{\circ} \mathrm{C}$. Then, all slides were placed in a electrophoresis tank containing electrophoresis buffer $[\mathrm{pH} \geq 13 ; 300 \mathrm{mM} \mathrm{NaOH}$, $1 \mathrm{mM}$ EDTA (both from Penta, Prague, Czech Republic)] and after 40 min of incubaton at $4{ }^{\circ} \mathrm{C}$ for alkali DNA unwinding, the electrophoresis was performed at $25 \mathrm{~V}$ and $300 \mathrm{~mA}(0.75$ $\mathrm{V} / \mathrm{cm}$ ) for $30 \mathrm{~min}$. After that, the slides were placed in neutralization buffer ( $\mathrm{pH}$ 7.5; 0.4 M Tris) (Penta, Prague, Czech Republic) three times for 5 min and washed with distilled water. Air dryed slides were rehydrated in deionized water and stained with $20 \mu \mathrm{l}$ of ethidium bromide $(20 \mu \mathrm{g} / \mathrm{ml}$; Sigma-Aldrich) before image analysis using Nikon epifluorescence microscope with LUCIA ${ }^{\circledR}$ comet assay software (Laboratory Imaging, Ltd., Prague, Czech Republic) for image analysis of the comets. Fifty cells per slide were scored and \%tail DNA value was used as a parameter of DNA damage. The extent of DNA liberated from the head of the comet is directly proportional to the amount of DNA damage (Collins, 2004).

\section{In vitro experiments}

Monolayers of human embryonic lung fibroblasts were seeded into $75 \mathrm{~cm}^{2}$ culture flask and grown to confluence. Soman was added to the culture medium at the concentrations 1000, 500, 250, 125 or $62.5 \mu \mathrm{g} / \mathrm{ml}$, respectively, for $1 \mathrm{~h}$ at $37^{\circ} \mathrm{C}$. After the treatment, the medium was exhausted, monolayers were washed with PBS and cells resuspended by trypsin in PBS. The suspension was used for the comet assay. Fifty cells were analysed per one estimation. The effect of soman was compared with the effect of hydrogen peroxide.

\section{In vivo experiments}

To evaluate the potency of nerve agents studied to induce oxidative damage of DNA, the rats were administered i. m. with sarin, soman or tabun at sublethal doses corresponding to 
$50 \%$ of their $\mathrm{LD}_{50}$ values or at lethal doses corresponding to their $\mathrm{LD}_{50}$ values. The rats were decapitated and exsanguinated to obtain the blood $30 \mathrm{~min}$ after nerve agent poisoning. The blood was centrifuged to obtain isolated lymphocytes. The tissues (liver, pontomedullar region of the brain) were removed and trypsinated to obtain hepatocytes and glial cells, as it was described in detail earlier (Richterova et al., 2018). DNA damage (direct single strand breaks) was evalutated with the help of Comet assay (single cell gel electrophoresis, SCGE). To detect oxidised bases of DNA, the enzyme endonuclease III was used (obtained from Dr. K. Angelis, Inst. of Eptl. Botany, Czech Acad Sci., Prague, Czech Republic) which is known to cleave oxidised pyrimidines. The evaluation of DNA damage was done in fluorescent microscope by image analysis Lucia G software involving the comet module (Laboratory Imaging, Prague, Czech Republic). For each experimental point, 50 cells were evaluated.

\section{Statistical analysis}

The differences among groups were calculated using KruskalWallis test and the statistical significance between control and experimental groups was tested by Mann-Whitney test. The differences were considered significant when $2 \alpha=0.05$.

\section{Results}

Contrary to hydrogen peroxide, soman did not induce any significant DNA damage in human fibroblasts in vitro within the broad range of concentration $(62.5-1000 \mu \mathrm{g} / \mathrm{ml})$ used (Table 1 ). As the in vitro results with soman were negative (without any effects), in vitro experiments with other nerve agents studied were not done.

Table 1. In vitro soman-induced DNA damage in human embryonic lung fibroblasts (\% DNA in tail of comet represents the amount of single strand breaks)

\begin{tabular}{lc}
\hline Concentration of soman $(\mu \mathrm{g} / \mathrm{ml})$ & \% DNA in tail of comet \\
\hline 0 & $2.5 \pm 1.3^{\mathrm{a}}$ \\
62.5 & $2.9 \pm 1.8$ \\
125 & $2.1 \pm 0.2$ \\
250 & $3.5 \pm 1.4$ \\
500 & $2.9 \pm 1.2$ \\
1000 & $3.8 \pm 1.9$ \\
Concentration of $\mathbf{H}_{\mathbf{2}} \mathbf{O}_{\mathbf{2}}(\boldsymbol{\mu M})$ & \\
20 & $12.5 \pm 3.9$ \\
100 & $38 \pm 7.2$ \\
\hline a means \pm SD & \\
\hline
\end{tabular}

In vivo experiments showed that lower dose of sarin or soman corresponding to $50 \%$ of $\mathrm{LD}_{50}$ did not induce any significant amount of oxidative DNA damage. When the lymphocytes or hepatocytes were incubated with the enzyme endonuclease III that is able to cleave oxidised pyrimidine bases, the percentage of DNA in the tail was usually higher compared to the cells without incubation with endonuclease III in experimental as well as control cells. The differences of the oxidative damage of DNA between cells from sarin or soman-poisoned rats and control rats were minimal (Tables 2-5).
Table 2. Sarin-induced DNA damage in peripheral lymphocytes (\% DNA in tail of comet represents the amount of single strand breaks)

\begin{tabular}{lccc}
\hline Treatment & $\begin{array}{c}\text { Presence of } \\
\text { endonuclease } \\
\text { III }\end{array}$ & $\begin{array}{c}\text { Percentage } \\
\text { of DNA in tail } \\
\text { of comet }\end{array}$ & $\begin{array}{c}\text { Number } \\
\text { of animals }\end{array}$ \\
\hline Saline controls & no & $0.095 \pm 0.038^{\mathrm{a}}$ & 6 \\
Sarin - 0.5 LD 50 & yes & $2.399 \pm 1.849$ & 6 \\
Saline controls & no & $0.782 \pm 1.351$ & 10 \\
& yes & $1.209 \pm 1.003$ & 10 \\
Sarin - LD 50 & no & $0.253 \pm 0.162$ & 6 \\
& yes & $3.090 \pm 1.497$ & 6 \\
\hline a means $\pm \mathrm{SD}$ & no & $0.198 \pm 0.314$ & 11 \\
\hline
\end{tabular}

Table 3. Sarin-induced DNA damage in hepatocytes (\% DNA in tail of comet represents the amount of single strand breaks)

\begin{tabular}{lccc}
\hline Treatment & $\begin{array}{c}\text { Presence of } \\
\text { endonuclease } \\
\text { III }\end{array}$ & $\begin{array}{c}\text { Percentage } \\
\text { of DNA in tail of } \\
\text { comet }\end{array}$ & $\begin{array}{c}\text { Number } \\
\text { of animals }\end{array}$ \\
\hline Saline controls & no & $13.389 \pm 4.688^{\text {a }}$ & 6 \\
Sarin -0.5 LD $_{50}$ & yes & $12.238 \pm 7.801$ & 6 \\
Saline controls & yes & $15.112 \pm 4.815$ & 10 \\
& no & $3.540 \pm 1.844$ & 6 \\
Sarin $-\mathrm{LD}_{50}$ & yes & $7.209 \pm 4.022$ & 6 \\
& no & $6.517 \pm 4.070$ & 11 \\
& yes & $\mathbf{1 5 . 2 8 1} \pm \mathbf{6 . 5 1 9 *}$ & 11 \\
\hline
\end{tabular}

a means $\pm \mathrm{SD}$

* significantly different from saline controls

Table 4. Soman-induced DNA damage in peripheral lymphocytes (\% DNA in tail of comet represents the amount of single strand breaks)

\begin{tabular}{lccc}
\hline Treatment & $\begin{array}{c}\text { Presence of } \\
\text { endonuclease } \\
\text { III }\end{array}$ & $\begin{array}{c}\text { Percentage } \\
\text { of DNA in tail } \\
\text { of comet }\end{array}$ & $\begin{array}{c}\text { Number } \\
\text { of animals }\end{array}$ \\
\hline Saline controls & no & $1.017 \pm 0.336^{\mathrm{a}}$ & 6 \\
Soman - 0.5 LD 50 & yes & $0.666 \pm 0.467$ & 6 \\
Saline controls & no & $0.094 \pm 0.018$ & 12 \\
& yes & $0.168 \pm 0.507$ & 12 \\
Soman $-\mathrm{LD}_{50}$ & yes & $1.128 \pm 1.694$ & 6 \\
& no & $0.814 \pm 0.937$ & 11 \\
\hline a means $\pm \mathrm{SD}$ & yes & $4.803 \pm 1.662$ & 11 \\
\hline
\end{tabular}


Table 5. Soman-induced DNA damage in hepatocytes (\% DNA in tail of comet represents the amount of single strand breaks)

\begin{tabular}{|c|c|c|c|}
\hline Treatment & $\begin{array}{c}\text { Presence of } \\
\text { endonuclease } \\
\text { III }\end{array}$ & $\begin{array}{c}\text { Percentage } \\
\text { of DNA in tail of } \\
\text { comet }\end{array}$ & $\begin{array}{l}\text { Number } \\
\text { of animals }\end{array}$ \\
\hline \multirow[t]{2}{*}{ Saline controls } & no & $4.838 \pm 2.510^{\mathrm{a}}$ & 6 \\
\hline & yes & $3.573 \pm 2.181$ & 6 \\
\hline \multirow[t]{2}{*}{ Soman $-0.5 \mathrm{LD}_{50}$} & no & $1.348 \pm 1.696$ & 12 \\
\hline & yes & $3.064 \pm 2.077$ & 12 \\
\hline \multirow[t]{2}{*}{ Saline controls } & no & $5.891 \pm 3.409$ & 6 \\
\hline & yes & $5.368 \pm 2.809$ & 6 \\
\hline \multirow[t]{2}{*}{ Soman - $\mathrm{LD}_{50}$} & no & $4.360 \pm 1.953$ & 11 \\
\hline & yes & $8.307 \pm 3.453^{*}$ & 11 \\
\hline $\begin{array}{l}\text { a means } \pm \text { SD } \\
{ }^{*} \text { significantly diff }\end{array}$ & from salin & rols & \\
\hline
\end{tabular}

Table 6. Soman-induced DNA damage in glial cells (\% DNA in tail of comet represents the amount of single strand breaks)

\begin{tabular}{lccc}
\hline Treatment & $\begin{array}{c}\text { Presence of } \\
\text { endonuclease } \\
\text { III }\end{array}$ & $\begin{array}{c}\text { Percentage } \\
\text { of DNA in tail } \\
\text { of comet }\end{array}$ & $\begin{array}{c}\text { Number } \\
\text { of animals }\end{array}$ \\
\hline Saline controls & no & $5.133 \pm 4.304^{\mathrm{a}}$ & 6 \\
Soman $-\mathrm{LD}_{50}$ & yes & $8.112 \pm 2.476$ & 6 \\
& no & $4.682 \pm 3.532$ & 6 \\
\hline
\end{tabular}

a means $\pm S D$

Table 7. Tabun-induced DNA damage in peripheral lymphocytes (\% DNA in tail of comet represents the amount of single strand breaks)

\begin{tabular}{lccc}
\hline Treatment & $\begin{array}{c}\text { Presence of } \\
\text { endonuclease } \\
\text { III }\end{array}$ & $\begin{array}{c}\text { Percentage } \\
\text { of DNA in tail } \\
\text { of comet }\end{array}$ & $\begin{array}{c}\text { Number } \\
\text { of animals }\end{array}$ \\
\hline Saline controls & no & $0.126 \pm 0.082^{\mathrm{a}}$ & 12 \\
Tabun - LD 50 & yes & $1.819 \pm 1.752$ & 12 \\
& no & $0.367 \pm 0.677$ & 16 \\
\hline a means \pm SD & yes & $1.820 \pm 3.228$ & 16 \\
\hline
\end{tabular}

Table 8. Tabun-induced DNA damage in hepatocytes (\% DNA in tail of comet represents the amount of single strand breaks)

\begin{tabular}{lccc}
\hline Treatment & $\begin{array}{c}\text { Presence of } \\
\text { endonuclease } \\
\text { III }\end{array}$ & $\begin{array}{c}\text { Percentage } \\
\text { of DNA in tail } \\
\text { of comet }\end{array}$ & $\begin{array}{c}\text { Number } \\
\text { of animals }\end{array}$ \\
\hline Saline controls & no & $7.708 \pm 5.458^{\mathrm{a}}$ & 12 \\
Tabun $-\mathrm{LD}_{50}$ & yes & $8.684 \pm 5.839$ & 12 \\
& no & $4.903 \pm 3.794$ & 16 \\
& yes & $6.012 \pm 2.379$ & 16 \\
\hline
\end{tabular}

${ }^{\mathrm{a}}$ means $\pm \mathrm{SD}$
Table 9. Tabun-induced DNA damage in glial cells (\% DNA in tail of comet represents the amount of single strand breaks)

\begin{tabular}{lccc}
\hline Treatment & $\begin{array}{c}\text { Presence of } \\
\text { endonuclease } \\
\text { III }\end{array}$ & $\begin{array}{c}\text { Percentage } \\
\text { of DNA in tail of } \\
\text { comet }\end{array}$ & $\begin{array}{c}\text { Number } \\
\text { of animals }\end{array}$ \\
\hline Saline controls & no & $8.030 \pm 2.728^{\mathrm{a}}$ & 6 \\
& yes & $6.824 \pm 2.487$ & 6 \\
Tabun - LD 50 & no & $\mathbf{1 2 . 2 9 2} \pm \mathbf{3 . 4 9 1}^{*}$ & 7 \\
& yes & $\mathbf{1 1 . 9 2 3} \pm \mathbf{4 . 6 4 4}^{*}$ & 7 \\
\hline a means \pm SD & & \\
${ }^{*}$ significantly different from saline controls & \\
\hline
\end{tabular}

In the case of higher doses of sarin or soman coresponding to $\mathrm{LD}_{50}$, a marked increase of oxidative DNA damage in peripheral lymphocytes and hepatocytes incubated with endonuclease III was found. However, the statistically significant differences between DNA damage in cells from control rats and cells from nerve agent-poisoned rats were observed in hepatocytes only. The difference between the amount of DNA oxidised bases in lymphocytes found in sarin-poisoned and control rats was not significant because of their high variability. The levels of DNA damage in hepatocytes was increased approximately two times in the case of sarin administration (Tables 2-5). On the other hand, marked DNA damage in glial cells from rats poisoned with soman was not observed (Table 6). Tabun administered at lethal dose was not able to markedly increase of DNA damage in lymphocytes as well as hepatocytes regardless of the incubation of cells with endonuclease III (Tables 7-8). However, it induced significant oxidative damage of DNA in glial cells from pontomedullar region of the brain (Table 9). As only peripheral compartment (lymphocytes and hepatocytes) was chosen at the beginning of our study (experiments with sarin), the ability of sarin to induce oxidative damage of DNA in glial cells was not investigated. Generally, the DNA damage was relatively low regardless of nerve agent used and type of cells investigated.

\section{Discussion}

Exposure to OPC produces indices of oxidative stress both in vitro and in vivo. In vitro incubation of OPC in cell models has been shown to increase the production of ROS and induce changes in endogenous antioxidant enzymes leading to free radical-mediated lipid peroxidation (Glutekin et al., 2000). In vivo studies have further confirmed that oxidative stress occurs in animals exposed to a wide variety of OPC in varying exposure paradigm, including subacute, acute and chronic exposures (Soltaninejad and Abdollahi, 2009). Humans exposed either acutely or chronically to OPC develop similar indices of oxidative stress, which include decreased antioxidant capacity, free radical-mediated DNA damage and free radical-mediated lipid peroxidation (Ranjbar et al., 2002, 2005; Shadnia et al., 2005). Evidence of elevated oxidative stress has been reported in cases of low-dose and long term poisoning with various OPC (Binukumar et al., 2010; Delgado et al., 2006; Elsharkawy et al, 2013; Possamai et al., 2007).

As described in above mentioned in vivo studies, in the case of low-level poisoning with OPC, no cholinergic signs and symptoms were observed when oxidative stress occured. It means that other mechanisms than $\mathrm{AChE}$ irreversible inhibition with subsequent overstimulation of muscarinic and 
nicotinic cholinergic receptors seem to be able to generate oxidative stress after OPC poisoning. The studies dealing with the occupational workers exposed chronically to low levels of OPC show alterations in antioxidant function, increased lipid peroxidation and increased free radical-mediated DNA damage (Muniz et al., 2008; Ranjbar et al., 2002). On the other hand, it was found that the degree of oxidative damage correlated with the degree of AChE inhibition (Kazi and Oommen, 2012; Ranjbar et al., 2002, 2005).

Exogenous and endogenous oxidants frequently cause oxidative damage of DNA (Halliwell, 1999). Therefore, one of the type of DNA damage after exposure to OPC is oxidative damage of DNA based on the development of OPC-induced oxidative stress. It is speculated that OPC phosphorylate proteins/ low molecule antioxidants, creating a pro-oxidative status. In addition, several studies have demonstrated that OPC bind to DNA (Zeljezic et al., 2016). DNA damage activates response machinery, including $\mathrm{p} 53, \mathrm{NF}-\mathrm{\kappa B}$, and MAPK pathways which regulate genes involved in ROS metabolism as well as $\mathrm{Ca}^{2+}$ homeostasis and apoptosis (Lee et al., 2014; Pejchal et al., 2009, RamaRao and Bhattacharya, 2012). Unrepaired DNA damage might induce cytokine cascade activation with subsequent pro-apoptotic mechanisms at the early time intervals (Kokkinakis et al., 2004) which might be followed by anti-apoptotic mechanisms in longer time intervals as observed in the study with soman-poisoned rats (Pejchal et al., 2008).

Our results demonstrate that DNA damage can be induced by nerve agents at high, lethal doses only. In the case of poisoning with sublethal doses of nerve agents studied, no significant DNA damage was observed. According to our knowledge, there is only one paper decribing the induction of the DNA damage by sarin in the blood leucocytes and parietal cortex in vivo in guinea pigs, which describes an increase in DNA fragmentation at 0.2 and $0.4 \mathrm{LD}_{50}$, but not at $0.1 \mathrm{LD}_{50}$ (Dave et al., 2007). However, sarin was administered repeatedly for 10 days in above mentioned study. No significant increase in DNA fragmentation in any experimental group at 17 days after sarin exposure was found (Dave et al., 2007). Our results presented in this paper confirm the ability of sarin, soman and tabun to induce the DNA damage in vivo. In addition, the increase of DNA damage by incubating of the analysed cells with endonuclease III highly suggests that nerve agents-induced DNA damage is not caused by direct interaction of nerve agents with DNA bases but it rather represents the oxidation of DNA bases. It is in accordance with our results in vitro, where any significant DNA damage after the treatment of human fibroblasts with soman was not observed. Gross with co-authors did not find any DNA damage in human small airway epithelial cells (SAEC) and normal human epidermal keratinocytes treated with soman or VX in vitro, either (Gross et al., 2010).

\section{Conclusions}

DNA damage caused by oxidation of DNA bases seems to be secondary toxic effect of nerve agents connected with general hypoxia and it is developed during severe poisoning with nerve agents. This non-cholinergic effect of nerve agents has probably consequences with nerve agents-induced hypoxic status during acute cholinergic crisis and it can contribute to their long-term toxic effects.

\section{Conflict of interests}

The authors report no conflict of interests. The authors alone are responsible for the content and writing of the paper.

\section{Acknowledgements}

The authors would like to thank to Mrs. V. Skrancova for her skilful technical assistance. The study was funded by a grant of Ministry of Defense of the Czech Republic - "Long term organization development plan - Medical Aspects of Weapons of Mass Destruction".

\section{References}

Bajgar J (2004). Organophosphate/nerve agent poisoning: mechanism of action, diagnosis, prophylaxis, and treatment. Adv Clin Chem 38: 151-216. DOI: 10.1016/S0065-2423(04)38006-6.

Binukumar BK, Bal A, Kandimalla R, Sunkaria A, Gill KD (2010). Mitochondrial energy metabolism impairment and liver dysfunction following chronic exposure to dichlorvos. Toxicology 270(2-3): 77-84. DOI: 10.1016/j.tox.2010.01.017.

Brocardo PS, Pandolfo P, Takahashi RN, Rodrigues AL, Dafre AL (2005). Antioxidant defenses and lipid peroxidation in the cerebral cortex and hippocampus following acute exposure to malathion and/or zinc chloride. Toxicology 207(2): 283-291. DOI: 10.1016/j. tox.2004.09.012.

Choi DW (1988). Calcium-mediated neurotoxicity: relationship to specific channel types and role in ischemic damage. Trends Neurosci 11(10): 465-469. DOI: 10.1016/0166-2236(88)90200-7.

Collins AR (2004). The comet assay for DNA damage and repair: principles, applications, and limitations. Mol Biotechnol 26(3): 249-261. DOI: 10.1385/MB:26:3:249.

Collins AR, Dusinska M, Gedik CM, Stetina R (1996). Oxidative damage to DNA: do we have a reliable biomarker? Environ Health Perspect 104(Suppl. 3): 465-469. DOI: 10.1289/ehp.96104s3465.

Collombet JM, Baubichon D, Four E, Sentenac-Masqueliez C, Lallement $G$ (2009). Effects of soman poisoning on mitochondrial respiratory enzymes activity in the mouse hippocampus and cerebral cortex. Drug Chem Toxicol 32(4): 405-410. DOI: 10.1080/01480540903019182.

Čolović MB, Krstić DZ, Lazarević-Pašti TD, Bondžić AM, Vasić VM (2013). Acetylcholinesterase inhibitors: pharmacology and toxicology. Curr Neuropharmacol 11(3): 315-335. DOI: 10.2174/1570159X11311030006.

Dave JR, Connors RA, Genovese RE, Whipple RA, Chen RW, DeFord SM, et al. (2007). DNA fragmentation in leucocytes following repeated low dose sarin exposure in guinea pigs. Cell Mol Life Sci 64(21): 2823-2828. DOI: 10.1007/s00018-007-7339-9.

Delfino RT, Ribeiro TS, Figueroa-Villar JD (2009). Organophosphorus compounds as chemical warfare agents: a review. J Braz Chem Soc 20(3): 407-428. DOI: 10.1590/S010350532009000300003.

Delgado EH, Streck EL, Quevedo J, Dal-Pizzol F (2006). Mitochondrial respiratory dysfunction and oxidative stress alter chronic malathion exposure. Neurochem Res 31(8): 1021-1025. DOI: 10.1007/s11064-006-9111-1.

Elsharkawy EE, Yahia D, El-Nisr NA (2013). Sub-chronic exposure to chlorpyrifos induces hematological, metabolic disorders and oxidative stress in rat: attenuation by glutathione. Environ Toxicol Pharmacol 35(2): 218-227. DOI: 10.1016/j.etap.2012.12.009.

Folbergova J, Kunz WS (2012). Mitochondrial dysfunction in epilepsy. Mitochondrion 12(1): 35-40. DOI: 10.1016/j. mito.2011.04.004.

Glutekin F, Ozturk M, Akdogan M (2000). The effect of organophosphate insecticide chlorpyrifos-ethyl on lipid peroxidation and antioxidant enzymes (in vitro). Arch Toxicol 74(9): 533-538. DOI: 10.1007/s002040000167.

Gross CL, Nealley EW, Miller AL, Nipwoda MT, Smith WJ (2010). Lack of genotoxicity in VX and soman-treated cultured human cells by comet assay analysis. J Med CBR Def 8: 1-12.

Gupta RC, Milatovic D, Dettbarn WD (2001). Depletion of energy metabolites following acetylcholinesterase inhibitor-induced status epilepticus: protection by antioxidants. Neurotoxicology 22(2): 271-282. DOI: 10.1016/S0161-813X(01)00013-4. 
Halliwell B (1999). Oxygen and nitrogen are pro-carcinogens. Damage to DNA by reactive oxygen, chlorine and nitrogen species: measurement, mechanism and effects of nutrition. Mutat Res 443(1-2): 37-52. DOI: 10.1016/s1383-5742(99)00009-5.

Ischiropoulos H, Beckman SM (2003). Oxidative stress and nitration in neurodegeneration: Cause, effect, or association? J Clin Invest 111(2): 163-169. DOI: 10.1172/JCI200317638.

Karami-Mohajeri S, Abdollahi M (2013). Mitochondrial dysfunction and organophosphate compounds. Toxicol Appl Pharmacol 270(1): 39-44. DOI: 10.1016/j.taap.2013.04.001.

Kassa J, Krocova Z, Vachek J (2000a). Long term alteration of immune functions following low level exposure to sarin in rats. Acta Med (Hradec Kralove) 43(3): 91-94. DOI: 10.14712/18059694.2019.119.

Kassa J, Skopec F, Vachek J (2000b). The long term changes in liver DNA and total protein contents following low level sarin exposure in rats. Acta Med (Hradec Kralove) 43(1): 19-22. DOI: 10.14712/18059694.2019.112.

Kaur P, Radotra B, Minz RW, Gill KD (2007). Impaired mitochondrial energy metabolism and neuronal apoptotic cell death after chronic dichlorvos exposure in rat brain. Neurotoxicology 28(6): 12081219. DOI: 10.1016/j.neuro.2007.08.001.

Kazi AI, Oommen A (2012). Monocrotophos induced oxidative damage associated with severe acetylcholinesterase inhibition in rat brain. Neurotoxicology 33(2): 145-161. DOI: 10.1016/j. neuro.2012.01.008.

Kokkinakis DM, Liu X, Chada S, Ahmed MM, Shareef MM, Singha UK, et al. (2004). Modulation of gene expression in human central nervous system tumors under methionine deprivation-induced stress. Cancer Res 64(20): 7513-7525. DOI: 10.1158/0008-5472.CAN-04-0592.

Kucharova M, Hronek M, Rybakova K, Zadak Z, Stetina R, Joskova V, Patkova A (2019). Comet assay and its use for evaluating oxidative DNA damage in some pathological states. Physiol Res 68(1): 1-15. DOI: 10.33549/physiolres.933901.

Lee JE, Lim MS, Park JH, Park CH, Koh HC (2014). Nuclear NF$\kappa \mathrm{B}$ contributes to chlorpyrifos-induced apoptosis through $\mathrm{p} 53$ signaling in human neural precursor cells. Neurotoxicology 42 : 58-70. DOI: 10.1016/j.neuro.2014.04.001.

Marrs TC (2007). Toxicology of organophosphate nerve agents. In: Marrs TC, Maynard RL, Sidell FR (Eds). Chemical warfare agents: toxicology and treatment. Chichester, West Sussex: John Wiley \& Sons, Ltd, pp. 191-221.

Mehta A, Verma RS, Srivastava N (2008). Chlorpyrifos-induced DNA damage in rat liver and brain. Environ Mol Mutagen 49(6): 426-433. DOI: 10.1002/em.20397.

Middlemore-Risher ML, Adam BL, Lambert NA, Terry AV (2011). Effects of chlorpyrifos and chlorpyrifos-oxon on the dynamics and movement of mitchondria in rat cortical neurons. J Pharmacol Exp Ther 339(2): 341-349. DOI: 10.1124/jpet.111.184762.

Muniz JF, McCauley L, Scherer J, Lasarev M, Koshy M, Kow YW, et al. (2008). Biomarkers of oxidative stress and DNA damage in agricultural workers: a pilot study. Toxicol Appl Pharmacol 227(1): 97-107. DOI: 10.1016/j.taap.2007.10.027.

O’Donnell JC, McDonough JH, Shih TM (2011). In vivo microdialysis and electroencephalographic activity in freely moving guinea pigs exposed to organophosphorus nerve agents sarin and VX: analysis of acetylcholine and glutamate. Arch Toxicol 85(12): 1607-1616. DOI: 10.1007/s00204-011-0724-z.

Ojha A, Yaduvanshi SK, Pant SC, Lomash V, Srivastava N (2013). Evaluation of DNA damage and cytotoxicity induced by three commonly used organophosphate pesticides individually and in mixture, in rat tissues. Environ Toxicol 28(10): 543-552. DOI: 10.1002/tox.20748.

Pearson JN, Patel M (2016). The role of oxidative stress in organophosphate and nerve agent toxicity. Ann N Y Acad Sci 1378(1): 17-24. DOI: 10.1111/nyas.13115.

Pejchal J, Österreicher J, Kassa J, Tichy A, Micuda S, Sinkorova Z, Zarybnicka L (2009). Soman poisoning alters p53 MAPK pathway in rat cerebellar Purkinje cells. J Appl Toxicol 29(4): 338-345. DOI: 10.1002/jat.1415.

Pejchal J, Österreicher J, Kassa J, Tichy A, Mokry J (2008). Activation of mitogen activated protein kinase (MAPK) pathways after soman poisoning in rat cerebellar granule neurons. J Appl Toxicol 28(5): 689-693. DOI: 10.1002/jat.1323.

Possamai FP, Fortunato JJ, Feier G, Agostinho FR, Quevedo J, Wilhelm D, Dal-Pizzol F (2007). Oxidative stress after acute and sub-chronic malathion intoxication in Wistar rats. Environ Toxicol Pharmacol 23(2): 198-204. DOI: 10.1016/j.etap.2006.09.003.

RamaRao G, Bhattacharya BK (2012). Multiple signal transduction pathways alteration during nerve agent toxicity. Toxicol Lett 208(1): 263-272. DOI: 10.1016/j.toxlet.2011.09.022.

Ranjbar A, Pasalar P, Abdollahi M (2002). Induction of oxidative stress and acetylcholinesterase inhibition in organophosphorous pesticide manufacturing workers. Hum Exp Toxicol 21(4): 179-182. DOI: 10.1191/0960327102ht238oa.

Ranjbar A, Solhim H, Mashayekhim FJ, Susanabdi A, Rezaie A, Abdollahi M (2005). Oxidative stress in acute human poisoning with organophosphorus insecticides: a case control study. Environ Toxicol Pharmacol 20(1): 88-91. DOI: 10.1016/j. etap.2004.10.007.

Richterova M, Stetina R, Jost P, Svobodova H, Rehacek V, Kassa J (2018). Inter strand crosslinks in DNA induced in vivo by percutaneous application of sulphur mustard to rats and mice. Mutat Res Genet Toxicol Environ Mutagen 832-833: 35-40. DOI: 10.1016/j.mrgentox.2018.06.014.

Shadnia S, Azizi E, Hosseini R, Khoei S, Fouladdel S, Pajoumand A, et al. (2005). Evaluation of oxidative stress and genotoxicity in organophosphorus insecticide formulators. Hum Exp Toxicol 24(9): 439-445. DOI: 10.1191/0960327105ht549oa.

Singh NP, McCoy MT, Tice RR, Schneider EL (1988). A simple technique for quantitation of low levels of DNA damage individual cells. Exp Cell Res 175(1): 184-191. DOI: 10.1016/00144827(88)90265-0.

Soltaninejad K, Abdollahi M (2009). Current opinion on the science of organophosphate pesticides and toxic stress: a systematic review. Med Sci Monit 15(3): RA75-90.

Zeljezic D, Mladinic M, Zunec S, Vrdoljak AL, Kusuba V, Tariba B, et al. (2016). Cytotoxic, genotoxic and biochemical markers of insecticide toxicity evaluated in human peripheral blood lymphocytes and an HepG2 cell line. Food Chem Toxicol 96: 90-106. 